\title{
Seasonal succession of epipelic algae: a case study on a mesotrophic pond in a temperate climate.
}

\author{
Jana ŠPAČKOVÁ ${ }^{1}$, Petr HAŠLER ${ }^{1}$, Jana ŠTĚPÁNKOVÁ ${ }^{1,2} \&$ Aloisie Poulí̌̌KOVÁ ${ }^{1}$ \\ ${ }^{1}$ Department of Botany, Faculty of Science, Palacký University, Svobody 26, CZ-771 46 Olomouc, Czech Republic; \\ e-mail: jana.spackov@seznam.cz \\ ${ }^{2}$ Department of Biology, Faculty of Education, Palacký University, Purkrabská 2, CZ-779 00 Olomouc, Czech \\ Republic
}

\begin{abstract}
The seasonal succession of algal species in the epipelon of shallow, mesotrophic pond Bezedník (Czech Republic) with special attention to diatoms (particularly Sellaphora) is described. The composition of epipelic algal assemblages changed over time in both higher taxonomic groupings and species representations. Spring and autumn were characterized by a dominance of diatoms; euglenophytes had their maximum in June and cyanobacteria were typical for the summer season. The occurrence of algal species also correlated with water temperature. However, although the growth of some species was restricted to a particular month, other species or species complexes had more extended growth periods. The genus Sellaphora has been selected to demonstrate variation in temporal distribution within species complexes.
\end{abstract}

Key words: epipelon, seasonal dynamics, mesotrophic pond, diatoms, cryptic species, Sellaphora

\section{Introduction}

Epipelon, defined as cyanobacteria and eukaryotic algae that live on or in association with fine-grained substrata, plays a key role in the functioning of freshwater ecosystems (PoulíčKová et al. 2008a). Despite their significance, many aspects of the temporal, spatial and geographical distribution, biodiversity, and ecology of epipelic algae are poorly understood (HAŠLER et al. 2008, HAŠLER \& PoulíčKová 2009, PoulíčKová et al. 2008a, b). The study of epipelic algal ecology in freshwater habitats was pioneered by Round $(1953,1972)$. However, interest did not develop to the same extent as in other important areas of freshwater research, most prominently the study of eutrophication and phytoplankton ecology. Some epipelic diatom species (Sellaphora pupula, $S$. bacillum) have proved to be complexes containing several morphologically similar species (MANN et al. 2008). Despite the fact that Sellaphora is the best-studied diatom genus in terms of cryptic diversity, the niche differentiation of these, often sympatrically occurring, semicryptic species is largely unknown (PoulíčKové et al. 2008b). The possibility that sympatric semicryptic species may co-occur because they have different seasonal occurrences should be tested. Fish ponds are man-made shallow water bodies in which water level, fish stock, and, to some extent, nutrient and fish-food input are under human control (FotT et al. 1980). This freshwater habitat type can be found in several European countries (e.g. Austria, Poland, Germany, Hungary, France, Croatia, Russia), and typically outnumbers larger lakes by a ratio of about 100:1 (OERTLI et al. 2005). In the Czech Republic they represent the single most common type of the stagnant water habitats (total area $510 \mathrm{~km}^{2}$; POKORNÝ et al. 2006), replacing a large proportion of former wetland ecosystems. The most recent papers, particularly focused on invertebrates or plants, highlight the importance of ponds for harbouring a large fraction of the total freshwater diversity (CÉRÉGHINO et al. 2008a,b, Davies et al. 2008, DE BIE et al. 2008). The spatial and temporal distribution patterns of epipelic algae in fish ponds remain largely unexplored, however (HAŠLER et al. 2008, PoulíčKová et al. 2008 a,b).

The present study, based on regular sampling of the model mesotrophic pond Bezedník (Moravia, Czech Republic), aims to describe the pattern of seasonal succession of pond epipelic 

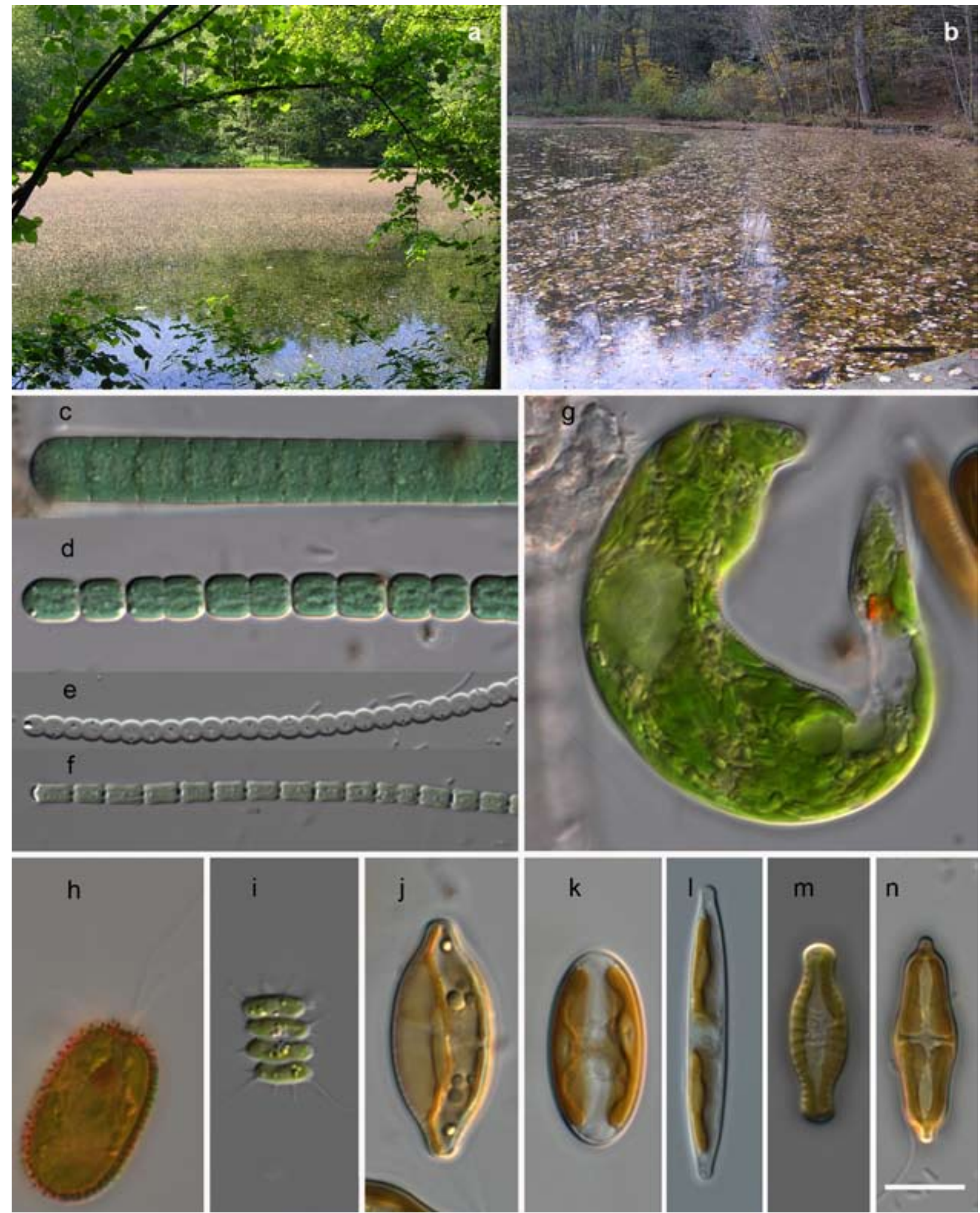

Fig. 1. Epipelic algae of National Nature Sanctuary Bezedník pond: (a) Bezedník in summer with population of Potamogeton crispus; (b) Bezedník in autumn with leaves; (c) Phormidium tergestinum; (d) Komvophoron constrictum; (e) K. cf. groenlandicum; (f) Pseudanabaena catenana; (g) Euglena deses; (h) Trachelomonas abrubta; (i) Scenedesmus subspicatus; (j) Placoneis sp.; (k) Fallacia sp.; (1) Nitzschia sp.; (m) Navicula sp.; (n) Stauroneis sp.; (g, h, j) images taken in 2008. Scale bar $10 \mu \mathrm{m}$. 

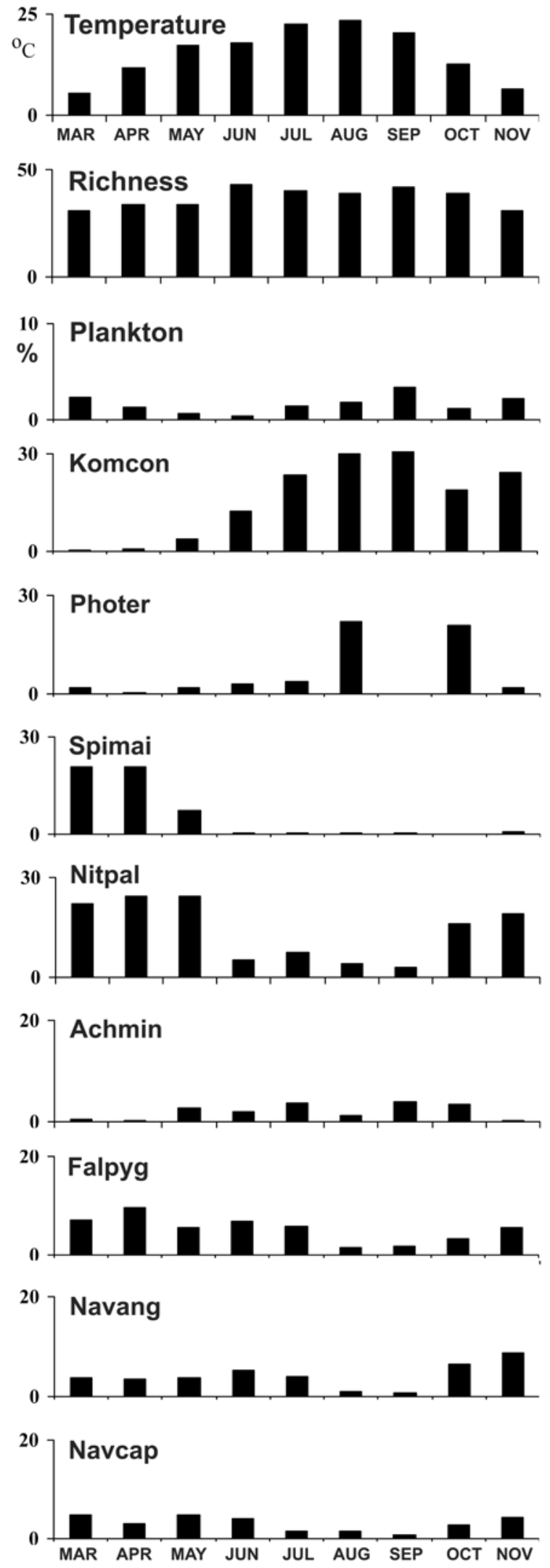
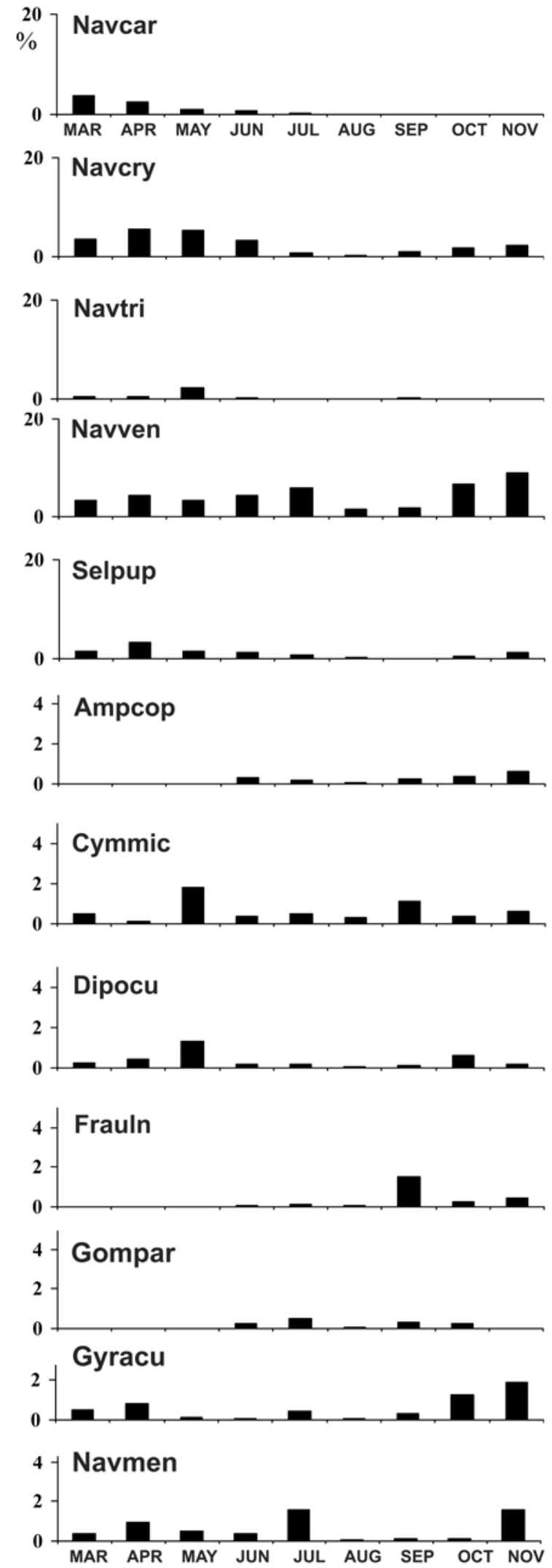

Fig. 2. Seasonal changes in temperature $\left({ }^{\circ} \mathrm{C}\right)$, species richness, occurrence of planktonic (plankton) and selected epipelic species (in \%): (Komcon) Komvophoron constrictum; (Photer) Phormidium terebriforme; (Spimai) Spirulina maior; (Nitpal) Nitzschia palea; (Achmin) Achnanthidium minutissimum; (Falpyg) Fallacia pygmaea; (Navang) Navicula angusta; (Navcap) Navicula capitata; (Navcar) Navicula capitatoradiata; (Navcry) Navicula cryptocephala; (Navtri) N. trivialis; (Navven) N. veneta; (Selpup) Sellaphora pupula; (Ampcop) Amphora copulata; (Cymmic) Cymbella microcephala; (Dipocu) Diploneis oculata; (Frauln) Fragilaria ulna; (Gompar) Gomphonema parvulum; (Gyracu) Gyrosigma acuminatum; (Navmen) Navicula menisculus. 
cyanobacteria and algae. A previous study of pools in England (Round 1972) provides a comparison with communities growing in different climate conditions (continental versus atlantic temperate climate).

\section{Materials and Methods}

The National Nature Sanctuary Bezedník (Czech Republic, GPS coordinates: $49^{\circ} 17^{\prime} 58^{\prime \prime} \mathrm{N}, 17^{\circ} 43^{\prime} 35^{\prime \prime} \mathrm{E}$; altitude $323 \mathrm{~m}$ a.s.1.), is a small, shallow, mesotrophic, forest pond (area $1.5811 \mathrm{ha}$, max. depth $2 \mathrm{~m}$, shading $50 \%$ ), and is protected as a place for amphibian reproduction (Fig. 1 a,b). Summer season is characterized by total coverage by submerged macrophyte Potamogeton crispus L. Environmental variables are described in detail elsewhere (conductivity $461-729 \mu{\mathrm{S} . \mathrm{cm}^{-1}}^{1}$, pH 8.6 - 9.1, Secchi disc transparency $75-200 \mathrm{~cm}$; HašLer et al. 2008, PoulíčKová et al. 2009).

Sediment samples were collected monthly (12.3., 2.4., 2.5., 18.6., 24.7., 5.8., 16.9., 29.10. and 30.11.) from March 2007 (after ice cover disappearance) to November 2007, using a glass tube, as described by Round (1953). They were transported to the laboratory in polyethylene bottles, poured out into plastic boxes and allowed to stand in the dark for at least $5 \mathrm{~h}$. The supernatant was then removed by suction and the mud was covered with lens tissue. Under continuous low level illumination (c. $5 \mu \mathrm{mol}$ photons $\mathrm{m}^{-2} \cdot \mathrm{s}^{-1}$ ) epipelic algae moved up through the first layer of lens tissue and became attached (within 24 hours of exposure) to the second layer of lens tissue and cover slips placed on top. Mostly autochtonous epipelic motile species are captured by this method, although some non-motile or sedimented planktonic species can be observed (Poulí̌́Koví et al. 2008a). Living cyanobacterial and algal cells, captured on cover slips were identified and counted (unicellular algae were counted as cells; colonies and filaments were counted as units $100 \mu \mathrm{m}$ long) on the same area $\left(22 \mathrm{~mm}^{2}\right)$ in native preparations (mounted in water) immediately after exposure. Diatoms captured in the second layer of the lens tissue were cleaned with a mixture of concentrated sulphuric and nitric acid and mounted in Naphrax as described previously by PoulíčKová \& Mann (2006). Species were identified according to Krammer \& LANGE Bertalot (1986, 1988, 1991a, b), HindÁk ed. (1978), and WolowsKi \& HindÁK (2005). Relative abundances of diatom species were estimated by counting 400 individuals from each sample.

The software package CANOCO for Windows 4.5 (TER BraAk \& ŠMilauer 2002) was used for multivariate statistical analyses. The epipelic diatom dataset (percentage of individual species in samples from March to November without any transformation) was analysed via principal components analysis (PCA). Water temperature was correlated with the results of the PCA (species scores) by non-parametric Spearman correlation ( $\mathrm{r}_{\mathrm{s}}$ ) using NCSS software. The correlation between Sellaphora pupula morphospecies occurrence (log-transformed data; $\mathrm{Y}^{\prime}=\log [\mathrm{A} . \mathrm{Y}+\mathrm{B}], \mathrm{A}=1, \mathrm{~B}$ $=1$ ) and water temperature was tested by redundancy analysis (RDA) with Monte Carlo permutition test under reduced model (499 unrestricted permutations).

\section{Results}

The pond under investigation (Fig. 1) is usually covered by ice and snow from December to February. The growth season in Bezedník started in 2007 in March, and the first sample was taken after complete disappearance of the ice cover. Water surface temperature ranged from $5{ }^{\circ} \mathrm{C}$ to 17 ${ }^{\circ} \mathrm{C}$ during the spring period (March-May), reached its maximum in August $\left(24{ }^{\circ} \mathrm{C}\right)$ and declined during late summer and autumn (Fig. 2).

The epipelic assemblages were dominated (in terms of abundance; cf. cell sizes of epipelic species in Fig. 1c-n) by Bacillariophyceae (60\%) during spring and autumn and by Cyanophyta (almost 80\%) during summer. Euglenophyta reached their seasonal maximum $(40 \%)$ in June (Fig. 3).

In total 93 species were found in the epipelon (including littoral or sedimented planktonic species; Table 1). Some representatives are illustrated in Fig. 1 c-n. Species richness was

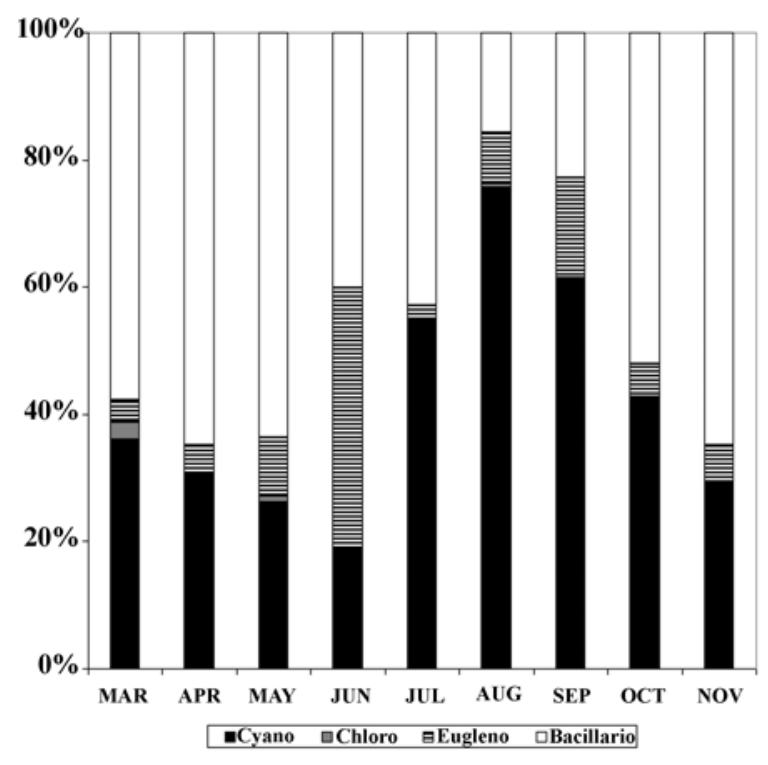

Fig. 3. Representation of epipelic algal groups during the growth season of 2007: (Cyano) Cyanophyta; (Chloro) Chlorophyta; (Eugleno) Euglenophyta; (Bacillario) Bacillariophyceae. 
similar during the whole year, with the exception of the summer months, when sedimented planktonic species enriched the assemblages (Fig. 2). Planktonic diatoms were represented by Cyclotella meneghiniana, Cyclotella pseudostelligera, Cyclotella stelligera, Nitzschia acicularis and Stephanodiscus cf. parvus.

The highest species richness was observed in the Bacillariophyceae (66 species). The most frequently encountered phototrophs were Komvophoron constrictum, Euglena cf. mutabilis and Nitzschia palea (Table 1). Some new species for the Czech Republic and science have been found within the cyanobacteria (Komvophoron hindakii sp. nov.; HaŠLER \& POULíčKOvÁ 2009).

Seasonal changes in relative abundances of selected algal species are illustrated in Fig. 2. All algal data were used for PCA analysis (Fig. 4). The first axis of the PCA, corresponding to the main variation in epipelic assemblages, separated the spring months from summer and autumn, while June was clearly separated from the other months on the second axis. Species like Spirulina maior, Navicula capitatoradiata, Sellaphora pupula and Navicula trivialis were most abundant in spring. Also Nitzschia palea and Diploneis oculata were identified mainly in spring with an additional increase in autumn. Some taxa were distributed more or less equally during the year, for example Navicula capitata, N. cryptocephala, Achnanthidium minutissimum. Komvophoron constrictum and Phormidium tergestinum were characteristic for the summer and autumn months. June differed significantly because of a dominance of Euglenophytes (Euglena mutabilis, E. oxyuris, Monomorphina pyrum).

The first and second axes of PCA ordination of epipelic algae explained 51 and $21.9 \%$ of the variance of species data respectively. The species turn-over over the first PCA axis was correlated with water temperature, diatoms were negatively correlated with water temperature (Spearman correlation for all epipelic species $\mathrm{r}_{\mathrm{s}}$ $=0.67, \mathrm{p}=0.05$; for diatoms only $\mathrm{r}_{\mathrm{s}}=-0,64, \mathrm{p}=$

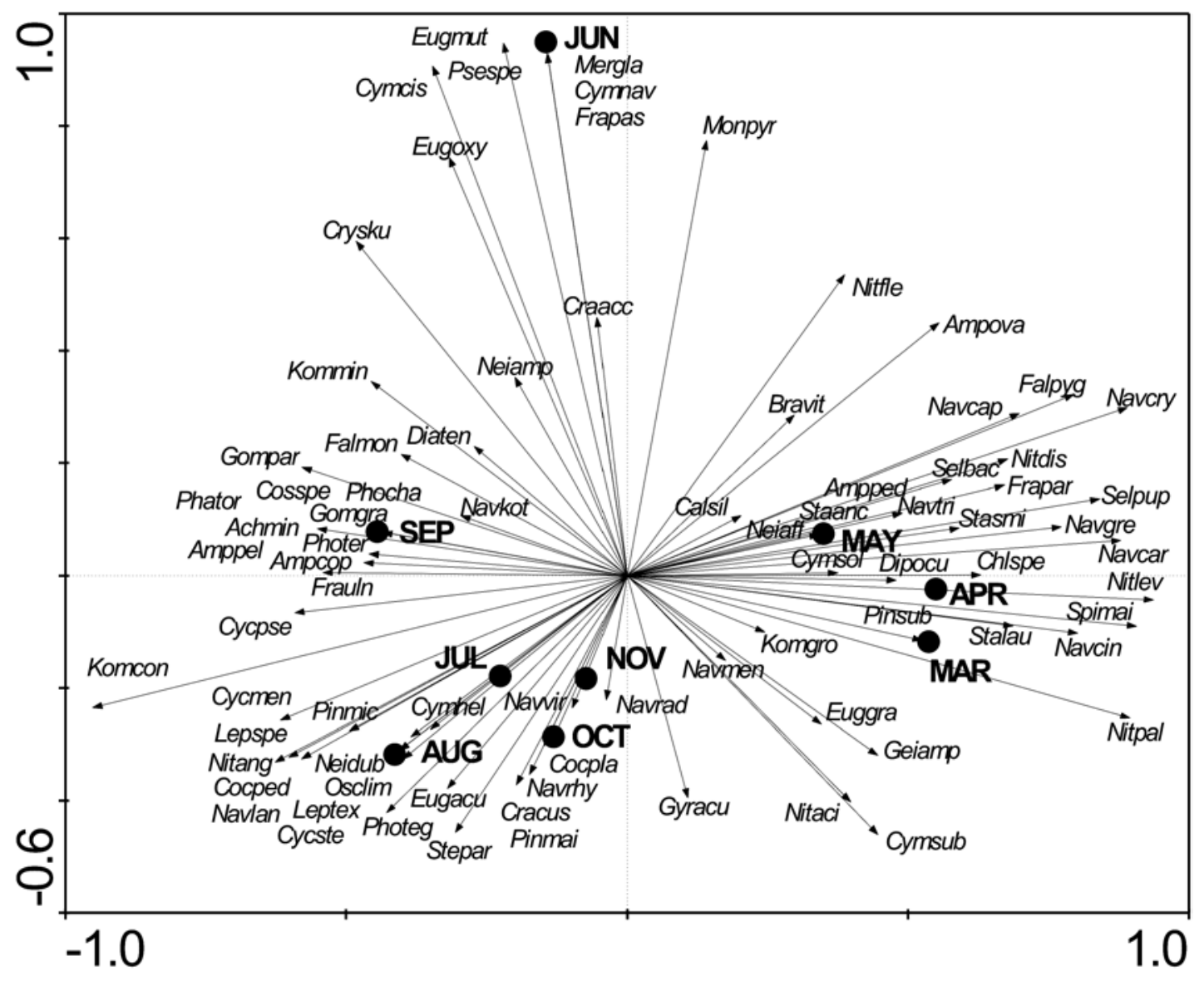

Fig. 4. PCA of epipelic species occurrence during the growth season of 2007 (months MAR - NOV, for species abbreviations see Table 1) 


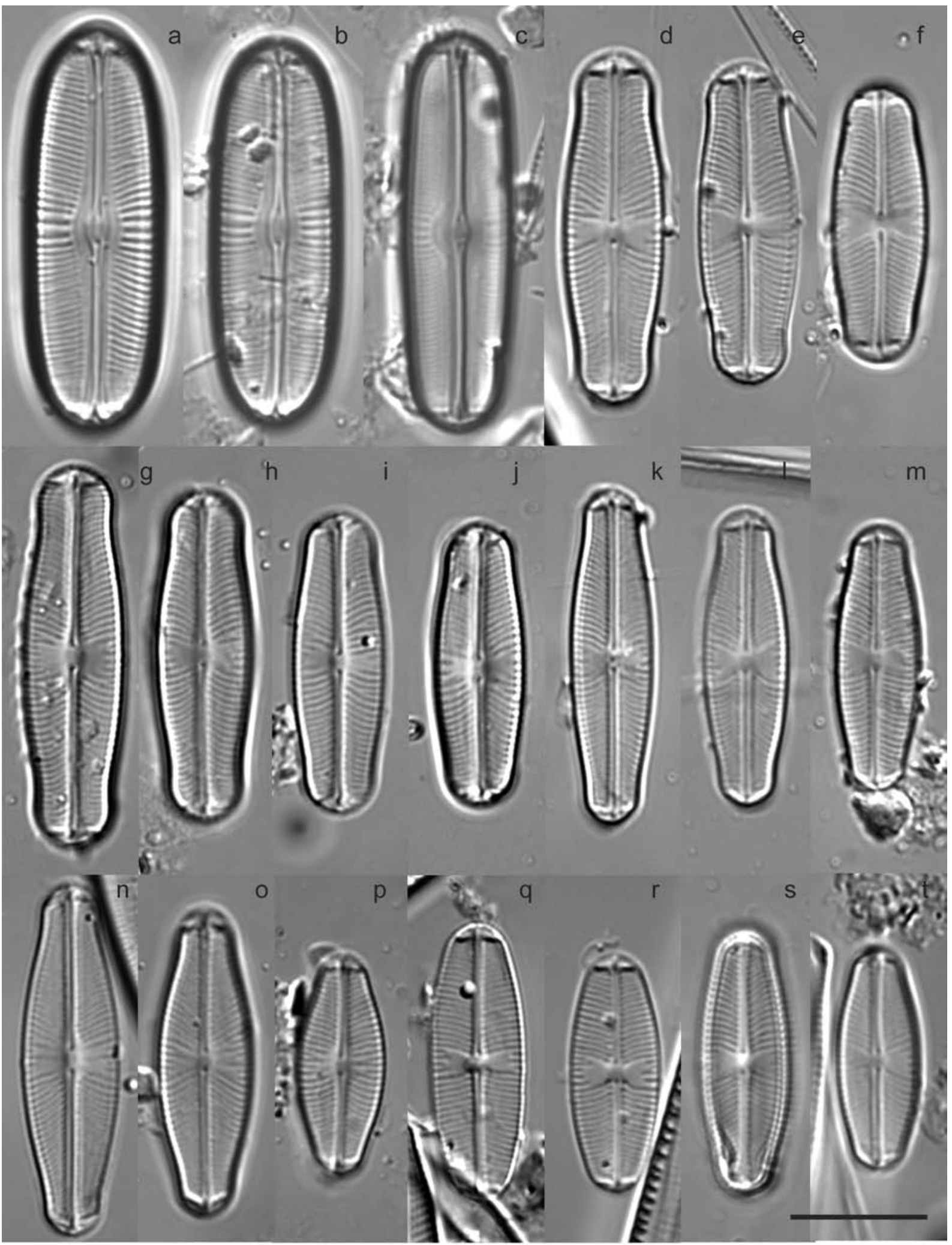

Fig. 5. (a-c) Sellaphora bacillum agg.; (d-t) Sellaphora pupula agg. [(d-j) capitate morphotypes A, (k-m) lanceolate morphotypes B with bow-tie-shaped central area, $(n-p)$ lanceolate morphotype $C$ with irregular central area, (q-r) elliptical morphotype D, (s-t) small morphotype E]. Scale bar $10 \mu \mathrm{m}$. 


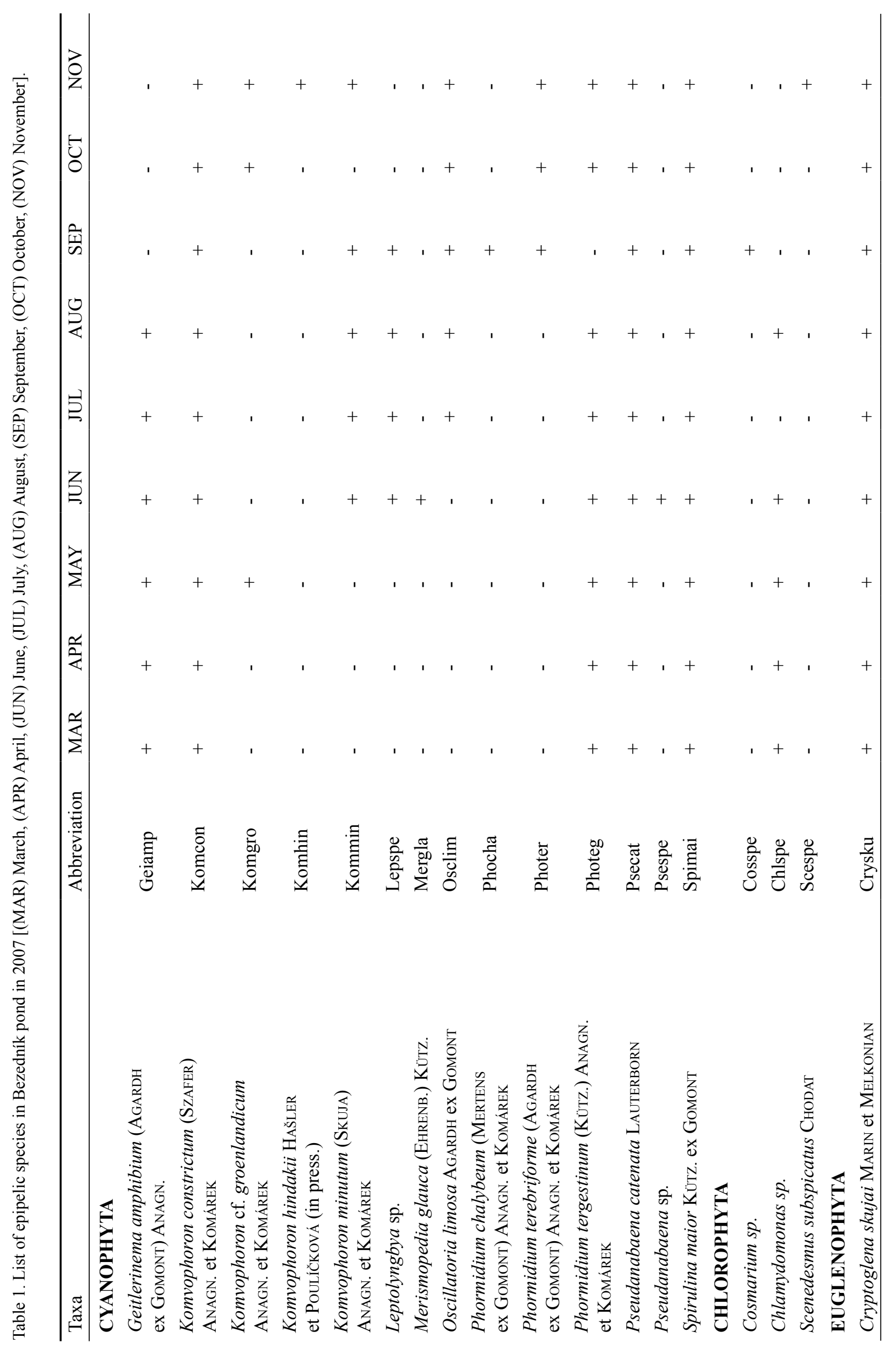




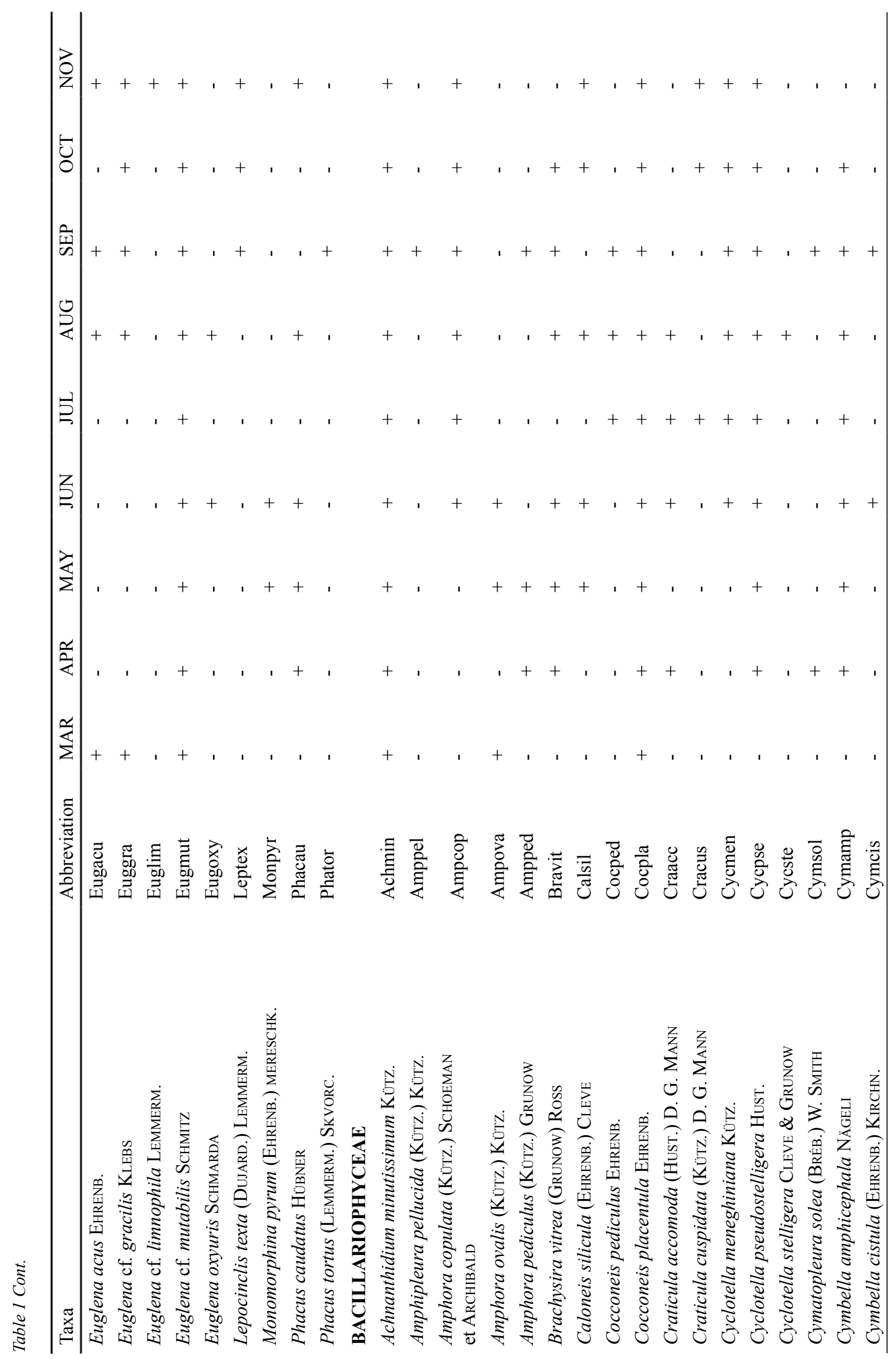




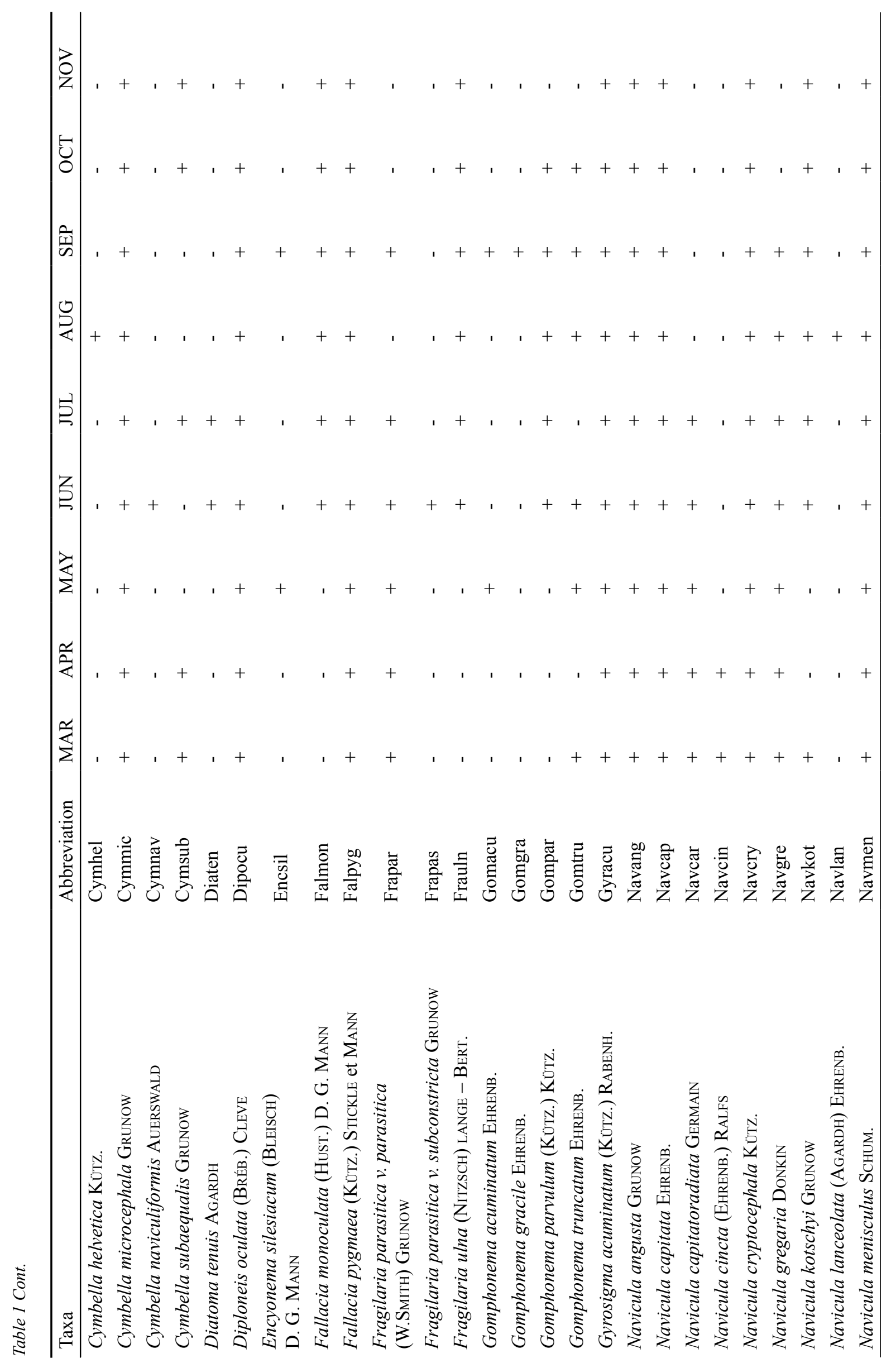




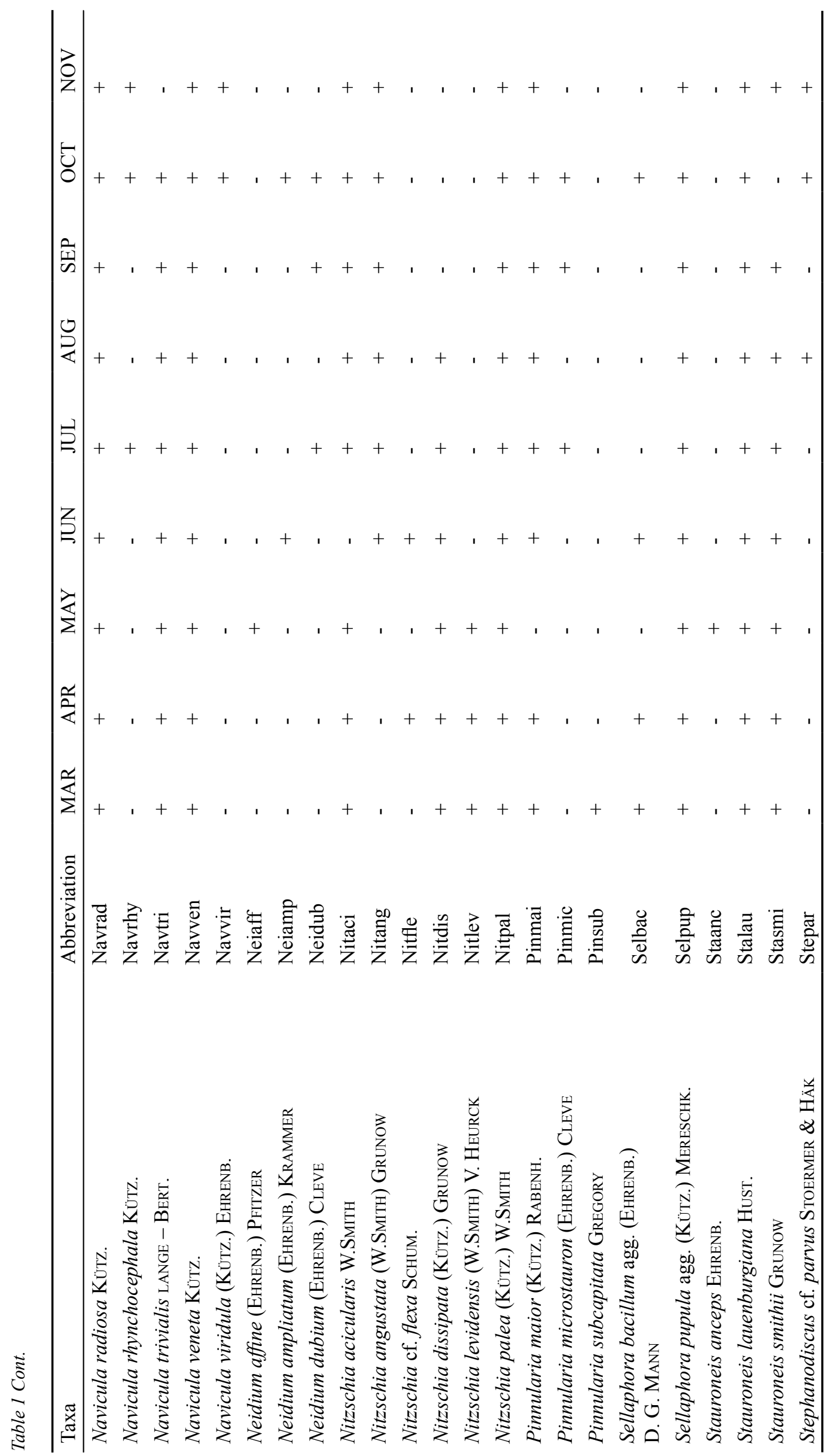


0.05 , for Sellaphora pupula species complex $\mathrm{r}_{\mathrm{s}}=$ $-0.73, \mathrm{p}=0.05$ ).

Sellaphora bacillum agg. (Fig. 5 a-c) occurred rarely $(<1 \%)$ during the whole year. Sellaphora pupula agg. represented $1-3 \%$ of epipelic assemblages in Bezedník, being rare within Central European lowland waters in contrast to British lakes (1-40\%; PoulíčKovÁ et al. 2008b). In Sellaphora pupula, several morphotypes with different seasonal occurrences could be distinguished (Fig. 6).

Capitate frustules of morphotype A (Fig. $5 \mathrm{~d}-\mathrm{j}$ ), which is most likely heterogenous, represented 30 to $70 \%$ of the Sellaphora specimens present (Fig. 6). Frequent was also lanceolate morphotype C (Fig. $5 \mathrm{n}-\mathrm{p}$ ) with irregular central area (5-50\%). Lanceolate morphotype B (Fig. 5 $\mathrm{k}-\mathrm{m})$ with bow-tie-shaped central area occured in winter-spring months. Elliptical morphotype D (Fig. 5 q-r) occurred only in August (37\%). Small morphotype E (Fig. $5 \mathrm{~s}-\mathrm{t}$ ) occurred irregularly (5-17\%). RDA (Fig. 7) showed that the influence of temperature on morphospecies occurrence was significant $(\mathrm{F}=2.44, \mathrm{p}=0.038)$. Morphotype $\mathrm{B}$ was negatively correlated with temperature, morphotype D was positively correlated with temperature. Morphotypes A and C separated on the second axis were more likely influenced by other factor not measured in this study.

\section{Discussion}

Much has been written over the years concerning the seasonal succession of planktonic algae, similar studies of epipelic communities are scarce (Round 1972).

For planktonic diatoms, it is wellestablished that seasonal changes are conditioned by fluctuations in environmental variables (LUND 1950). However, the measurements of these factors in an interface between mud and water, inhabited by epipelon, is difficult. Spring and autumn diatom maxima (both planktonic and benthic) are usually explained by fluctuations in silica concentrations (JEwson 1992, Round 1953). This is true for deep large lakes, but the situation in shallow ponds may be different (PoulíčKové 1999).

Round published a three year study of epipelon seasonal dynamics from small, extremely shallow (up to $50 \mathrm{~cm}$ ) ponds withouth thermal stratification, situated in the Botanical Garden in Birmingham (Round 1972). A characteristic of the seasonal cycles was their general reproducibility from year to year. Bezedník is a slightly deeper pond $(200 \mathrm{~cm})$ without summer thermal stratification, the only stratification can be found in winter, when the surface is covered by ice and snow and conditions near the bottom are characterized by a water temperature of $4{ }^{\circ} \mathrm{C}$, very low light, high content of organic matter (leaves from surrounding trees and decaying parts of submerged macrophytes e.g. Potamogeton crispus L., Fig. 1a,b) and almost anoxic conditions (HAŠLER \& PoulíčKovÁ 2009). In contrast to Round's paper, the seasonal maximum of Euglenophytes in June corresponded well with an increase of organic matter content. Organic matter content started to increase in summer due to the collapse of populations of the submerged macrophyte Potamogeton crispus at the end of their vegetation season (HAŠLER \& PoulíčKOvÁ 2009). The mud became black and anoxic. These conditions were tolerated also by some cyanobacteria, particularly Komvophoron constrictum. Cyanobacterial summer dominance correspond also with their inclination to higher temperatures, the same pattern is known from plankton (REYNOLDS 1986). The only exception was represented by Spirulina maior with spring occurrence.

Despite climate and site condition differences, we have found a similar pattern in the occurrence of several joint epipelic species studied by Round (1972): Navicula capitata (formely $N$. hungarica var. capitata), Navicula cryptocephala, Sellaphora pupula (formely Navicula pupula), Nitzschia acicularis, and Nitzschia palea. Three species, Navicula capitata, N. cryptocephala and Niztzschia palea can be characterized as species ocurring the whole year with a slightly lower abundance in summer. The more extended growth periods of these species were also noticed by Round (1972). He discussed particularly N. palea and $N$. cryptocephala, of which he suggested that they might include several morphologically similar forms. In fact, he predicted the existence of cryptic species within these species complexes, which was only recognized formally much later (Trobajo et al. 2006, PoulíčKová \& MANN 2006). Achnanthidium minutissimum belongs to the same category of morphologically heterogenous species (Potapova \& Hamilton 2007). The occurrence of Nitzschia acicularis corresponded to the occurrence of other mid-summer (high light and temperature) planktonic species.

Sellaphora pupula agg. exhibited a winter- 
spring occurrence and significant negative correlation with water temperature. Differences in representation of Sellaphora within epipelic assemblages between Great Britain and Central Europe (PoulíčKová et al. 2008b, PoulíčKová et al. in press.) can be explained by climate differences. Morphotypes within Sellaphora pupula species complex observed in the Bezedník pond, differed in their occurrence and relations to temperature. Positive correlation with water temperature was

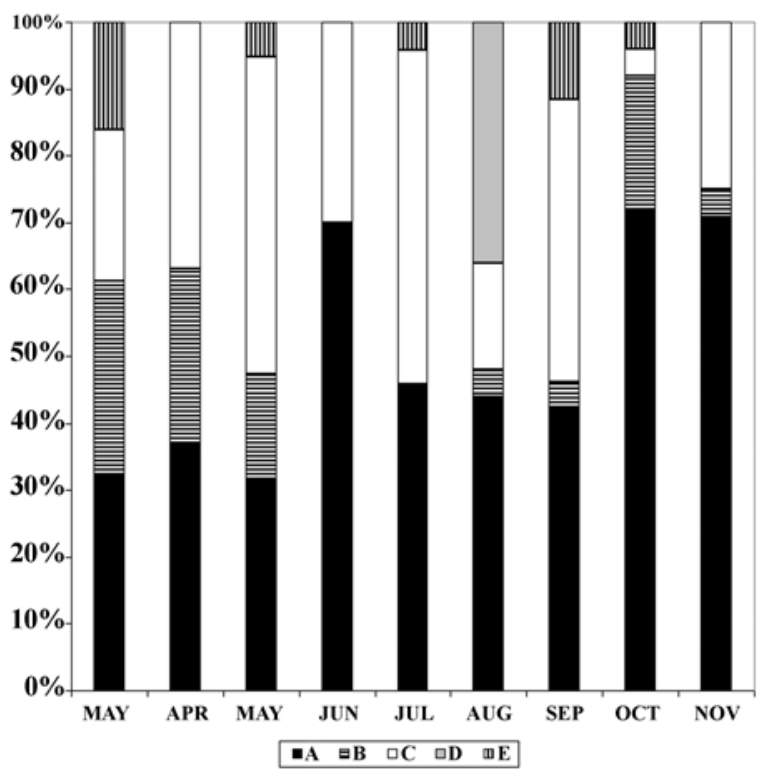

Fig. 6. Representation of Sellaphora pupula morphotypes in Bezedník during the growth season of 2007: (A) capitate morphotype A; (B) lanceolate morphotype B with bowtie-shaped central area; (C) lanceolate morphotype $\mathrm{C}$ with irregular central area; (D) elliptical morphotype D; (E) small morphotype E.

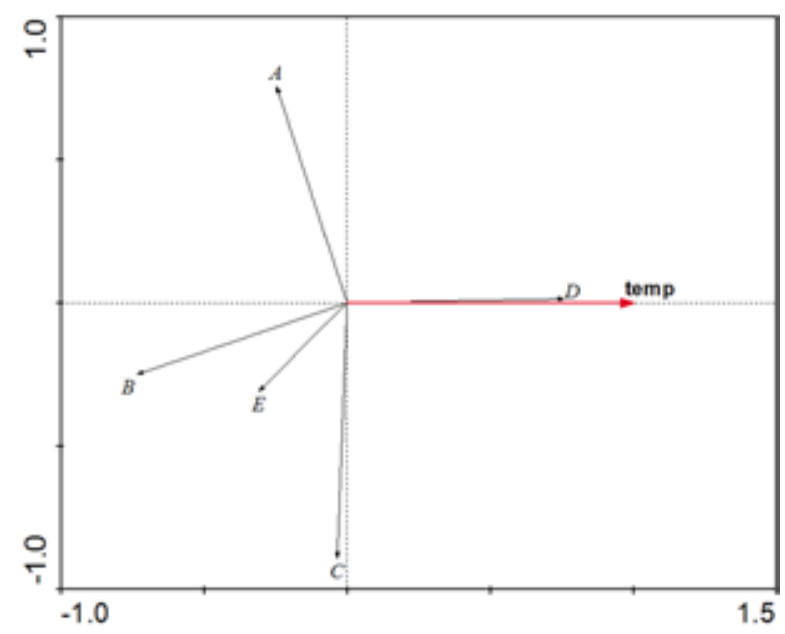

Fig. 7. RDA analysis, correlation between Sellaphora pupula morphospecies occurrence and water temperature. rare, exhibited only by elliptical morphotype D. Morphospecies without any temperature/ season preferences seems to be morphologically heterogenous. Round (1972) mentioned two morphospecies (Navicula pupula and N. pupula var. capitata). The extreme semicryptic diversity was not known at that time. The Sellaphora species complex consists of at least 50 morphospecies within Great Britain (MANN et al. 2008); some of these morphospecies (demes) are ecologically differentiated (PoulíčKovÁ et al. 2008b) and more than two co-exist in the same lake (MANN et al. 2008, PoulíčKoví et al. 2008b). Although some of the morphospecies found in Bezedník resemble the demes from Great Britain (MANN et al. 2008), their taxonomical position is uncertain. Bar-coding data obtained in case of 15 Sellaphora clones, isolated from other Czech ponds (no data exist for Bezedník's morphotypes) showed, that most of Czech and British demes differ genetically on the species level (Evans, unpublished). The morphological variation illustrated here (Fig. 5) suggest, that Bezedník is inhabited by several demes of the Sellaphora pupula agg. Two morphotypes, which seem to be homogenous morphologically, can be selected as an example of two extremes in temporal distribution. In contrast to elliptical morphotype $\mathrm{D}$ which occurred only in August, lanceolate morphotype $\mathrm{C}$ was frequent all over the year. The same pattern was observed in some cyanobacteria (HAŠLER \& PoulíčKovÁ 2009), which means, that some eurytope species may exist, but this hypothesis need confirmation on genetic level.

\section{Acknowledgement}

This study was supported by grants no. 206/07/0115 and 206/08/0389 of Czech Science Foundation. We are grateful to Pieter Vanormelingen (University of Ghent, Belgium) for comments on the manuscript and linguistic corrections.

\section{References}

Céréghino, R., Biggs, J., Oertli, B. \& Declerck, S. (2008a): The ecology of European ponds: defining the characteristics of a neglected freshwater habitat. Hydrobiologia 597: 1-6.

Céréghino, R., Ruggiero, A., Marty, P. \& Angélibert, S. (2008b): Biodiversity and distribution patterns of freshwater invertebrates in farm ponds of a south-western French agricultural landscape. Hydrobiologia 597: 43-51.

Davies, B.R., Biggs, J., Williams, P.J., Lee, J.T. \& Thompson, 
S. (2008): A comparison of the catchment sizes of rivers, streams, ponds, ditches and lakes: implications for protecting aquatic biodiversity in an agricultural landscape. - Hydrobiologia 597: 7-17.

De Bie, T., Declerck, S., De Meester, L., Martens, K. \& BRENDONCK, L. (2008): A comparative analysis of cladoceran communities from different water body types: patterns in community composition and diversity. - Hydrobiologia 597: 19-27.

Fott, J., Pechar, L. \& Praž́́ková, M. (1980): Fish as a factor controlling water quality in ponds. - In: BARICA, J. \& Mur, L.R. (eds): Hypertrophic Ecosystems. Developments in Hydrobiology 2: 255-261.

Hašler, P. \& PoulíčKovÁ, A. (2009): Diversity, taxonomy and autecology of autochtonous epipelic cyanobacteria of the genus Komvophoron (Borziaceae, Oscillatoriales): a study on populations from the Czech Republic and British Isles. - Biologia, in press.

Hašler, P., Štěpánková, J., ŠpačKová, J., Neustupa, J., Kitner, M., Hekera, P., Veselá, J., Burian, J. \& PoulíčKovÁ, A. (2008): Epipelic cyanobacteria and algae: a case study from Czech fishponds. - Fottea 8: $133-146$.

HindÁk, F. (ed.) (1978) : Sladkovodné riasy. - 724 pp., SPN, Bratislava.

Jewson, H.D. (1992): Life cycle of a Stephanodiscus sp. - J. Phycol. 28: 856-866.

Krammer, K. \& Lange-Bertalot, H. (1986): Bacillariophyceae. 1. Teil. - In: Ettl, H., Gerloff, J., Heynig, H. \& Mollenhauer, D. (eds): Süßwasserflora von Mitteleuropa, Vol. 2/1. - 876 pp., G. Fischer, Stuttgart \& New York.

Krammer, K. \& Lange - Bertalot, H. (1988): Bacillariophyceae. 2. Teil. - In: Ettl, H., Gerloff, J., Heynig, H. \& Mollenhauer, D. (eds): Süßwasserflora von Mitteleuropa, Vol. 2/2. - 611 pp., G. Fischer, Stuttgart \& New York.

Krammer, K. \& Lange-Bertalot, H. (1991a): Bacillariophyceae. 3. Teil. - In: Ettl, H., Gerloff, J., Heynig, H. \& Mollenhauer, D. (eds): Süßwasserflora von Mitteleuropa, Vol. 2/3. - 599 pp., G. Fischer, Stuttgart \& New York.

Krammer, K. \& Lange-Bertalot, H. (1991b): Bacillariophyceae. 4. Teil. - In: EtTl, H., Gerloff, J., Heynig, H. \& Mollenhauer, D. (eds): Süßwasserflora von Mitteleuropa, Vol. 2/4. - 468 pp., G. Fischer, Stuttgart $\&$ New York

Lund, J.W.G. (1950): Studies on Asterionella formosa Hass. II. Nutrient depletion and the spring maximum. - J. Ecol. 38: 1-35.

Mann, D.G., Thomas, S.J. \& Evans, K.M. (2008): Revision of the diatom genus Sellaphora: a first account of the larger species in the British Isles. - Fottea 8: 15-78.

Oertli, B., Biggs, J., Céréghino, R., Grillas, P., Joly, P. \& Lachavanne, J.B. (2005): Conservation and monitoring of ponds diversity: introduction.-Aquatic Conservation: Marine and Freshwater Ecosystems 15: 535-540.

Pokorný, D., PešEk, V. \& MedunovÁ, A. (2006): Voda v ČR do kapsy [Water to the pocket]. -99 pp., Ministry of Agriculture CR, Prague.

Potapova, M. \& Hamilton, P. B. (2007): Morphological and ecological variation within the Achnanthidium minutissimum (Bacillariophyceae) species complex. - J. Phycol. 43: 561-575.
PoulíčKovÁ, A. (1999): Morphological variability of Stephanodiscus hantzschii under ecological conditions of the Vajgar fishpond. - Algological Studies 92: 57-71.

PoulíčKovÁ, A. \& ManN, D.G. (2006): Sexual reproduction in Navicula cryptocephala (Bacillariophyceae). - J. Phycol. 42: 872-886.

PoulíčKová, A., Hašler, P., Lysáková, M. \& Spears, B. (2008a): The ecology of freshwater epipelic algae: an update. - Phycologia 47: 437-450.

PoulíčKovÁ, A., ŠPačKovÁ, J., Kelly, M.G., Duchoslav, M. \& MANN, D. G. (2008b): Ecological variation within Sellaphora species complexes (Bacillariophyceae): specialists or generalists? - Hydrobiologia 614: 373-386.

PoulíčKovÁ, A., Neustupa, J., ŠPaČKovÁ, J. \& ŠKaloud, P. (2009): Distribution of epipelic diatoms in artificial fishponds along environmental and spatial gradients. - Hydrobiologia 624: 81-90.

Reynolds, C.S, (1986): The ecology of freshwater phytoplankton. - 381 pp., Cambridge University Press, Cambridge.

Round, F.E. (1953): An investigation of two benthic algal communities in Malham Tarn, Yorkshire. - J. Ecol. 41:174-179.

Round, F.E. (1972): Patterns of seasonal succession of freshwater epipelic algae. - Br. phycol. J. 7: 213220.

TER BRAAK, C.J.F. \& P. ŠMILAUER (2002): CANOCO reference manual and CanoDraw for windows users'guide: Software for canonical community ordination (version 4.5). Microcomputer Power, Ithaca, USA.

Trobajo, R., Mann, D.G., Chepurnov, V.A., Clavero, E. \& Cox, E.J. (2006): Taxonomy, life cycle, and auxosporulation of Nitzschia fonticola (Bacillariophyta). - J. Phycol. 42: 1353-1372.

Wolowski, K. \& HindÁK, F. (2005): Atlas of Euglenophytes. -136 pp., Veda, Bratislava.

(C) Czech Phycological Society

Received November 12, 2008

Accepted January 20, 2009 